Demerec, director, Department of Genetics, Carnegie Institution of Washington, Cold Spring Harbor ; Dr. Jesse Douglas, Department of Mathematics, Brooklyn College; Dr. Clarence H. Graham, Department of Psychology, Columbia University; Dr. Morris S. Kharasch, Department of Chemistry, University of Chicago; Dr. Karl Paul Link, professor of biochemistry, Agricultural Experiment Station, University of Wisconsin; Dr. Robert F. Loeb, College of Physicians and Surgeons, Columbia University; Dr. Esmond R. Long, Henry Phipps Institute, 7th and Lombard Streots, Philadelphia, Pa. ; Dr. Joseph E. Mayer, Department of Chemistry, Columbia University; Dr. Charles S. Piggot, Geophysical Laboratory, Carnegie Institution of Washington ; Dr. Marcus M. Rhoades, Department of Botany, Columbia University ; Dr. George Scatchard, Department of Chemistry, Massachusetts Institute of Technology ; Dr. Tracy M. Sonneborn, Department of Zoology, Indiana University; Dr. Leslie Spier, P.O. Box 880, Santa Cruz, California; Dr. S. Smith Stevens, Department of Psychology, Harvard University ; Dr. Chauncey G. Suits, director of the Research Laboratory, General Electric Company, Schenectady, New York; Dr. Frederick E. Terman, dean of the School of Engineering, Stanford University; Dr. Merle A. Tuve, director of the Department of Terrestrial Magnetism, Carnegie Institution of Washington ; Dr. Chester H. Werkman, head of the Depart. ment of Bacteriology, Iowa State College; Dr. Roger J. Williams, director of the Biochemical Institute, University of Texas; Dr. Frank C. Whitmore, dean of the School of Chemistry and Physics, Pennsylvania State College; Dr. Wendell P. Woodring, principal geologist, United States Geological Survey.

The following have been elected foreign associates of the National Academy of Sciences : Prof. Sydney Chapman, Sedleian professor of natural philosophy, University of Oxford ; Dr. Peter Kapitza, director of the Institute for Physical Problems, Academy of Sciences of U.S.S.R.

\section{National Research Council of Canada : Medical Fellowships}

PosT-GRADUATE medical fellowships have been awarded for 1946-47 by the National Research Council of Canada for the first time. Three junior awards (1,200 dollars a year) and five intermediate awards (1,800 dollars a year) have been announced : provision has also been made for senior awards (2,400 dollars a year). Junior fellowships are open to graduates in medicine who have already completed one year of post-graduate study; inter. mediate fellowships to applicants who have had experience in research work in a medical science for at least one year following graduation; senior fellowships are for applicants who have given evidence of capacity to conduct independent research in medical science. The awards for $1946-47$ are as follows : Junior Fellowships : Dr. M. Hendelman (McGill), at the Royal Victoria Hospital, Montreal (obstetrics and gynæcology); Dr. Levitan (McGill), at MeGill University (physiology); Dr. D. L. Wilson (Queen's), at the University of Toronto (biochemistry). Intermediate Fellowships: Dr. P. Dontigny (Laval and Montreal), at the Institute of Experimental Medicine and Surgery, Montreal (endocrinology); Dr. A. Gold (MeGill), at MeGill University (endocrinology); Dr. J. Leger (Montreal), at the Institute of Experimental Medicine and Surgery, Montreal (endocrino. logy and allergy) ; Dr. K. R. Mackenzie (McGill), at the University Clinic, Royal Victoria Hospital, Montreal (experimental medicine); Dr. G. C. McMillan (McGill), at the Pathological Institute, MeGill University (pathology).

\section{Indian Statistical Institute}

AT the fourteenth annual general meeting of the Indian Statistical Institute, held on April 27 in Calcutta, the following officers were elected tor the session 1946-47 : President, Sir C. D. Deshmukh; Hon. Vice-Presidents (having filled the office of president), Sir Badridas Goenka, Mr. N. R. Sarker ; Vice-Presidents, Dr. P. N. Banerjea, Sir A. H. Ghuznavi, Sir T. E. Gregory, Dr. S. P. Mookerjee, Sir C. W. B. Normand, Mr. Chandmull Rajgharia, Sir Shri Ram, Sir C. V. Raman, the Hon. Justice T. J. Y. Roxburgh, the Hon. H. S. Suhrawardy; Treasurer, Dr. Satya Churn Law; Secretary, Prof. P. C. Mahalanobis (on leave), Prof. S. N. Bose (to act in his place); Joint Secretaries, Prof. K. N. Chakravorti, Kumar Bimal Chandra Sinha.

As in previous years, the Indian Statistical Institute has continued during the past year its usual activity along various lines of theoretical and applied research. It undertook and carried out various types of statistical surveys, among which may be mentioned a comprehensive crop survey in Bengal covering jute, Aus paddy, and Aman paddy, population forecasts, and inquiries relating to the economics and statistics of road development projects, the economic condition of agricultural labour in Bengal, rural indebtedness, and the family budget of middle class employees in Bengal. A sample survey of the after-effects of the Bengal famine of 1943 undertaken by the Institute in collaboration with Prof. K. P. Chattopadhyaya of the University of Calcutta mainly from the point of viow of rehabilitation culminated in a comprehensive paper on the subject recently published. Government servants from many parts of India and students from various universities received training at the Institute. A special course in industrial statistics was also instituted last year and was largely a.ttended. Prof. P. C. Mahalanobis, honorary secretary of the Institute, has recently been carrying out work in New York for the United Nations Organisation and is now taking part in the Royal Society Empire Scientific Conference being held in Great Britain.

\section{Radiobiological Research}

A RECENT number of the British Medical Bulletin (Vol. 4, No. 1, 1946. 7s.) is entitled "Radiobiology, Experimental and Applied". This volume is the second of a series concerned with the applications of physies in medicine and contains twelve reviews. The subjects include most of the problems of contemporary interest in relation to the scientific basis of radiotherapeutics. The introductory article by Dr. F. G. Spear summarizes the whole field of radiobiological research and includes an instructive plate illustrating the relationship between cell division and cell differentiation in normal tissues. Dr. L. H. Gray contributes a valuable review of the influence of 'linear ion density' (specific ionization) on the relative biological efficiency per ion pair. The genetic effects of radiations are lucidly summarized by Dr. D. G. Catcheside. The article by Dr. D. E. Lea on the action of radiation on viruses and bacteria is an only too brief survey of a subject to which he has so largely contributed. Radiotherapists will be especially 